\title{
Studies on Homalomeneae (Araceae) of Borneo XXI: A New Karst Limestone Obligated Homalomena Species Endemic to Niah Caves
}

\author{
PETER C. BOYCE

\begin{abstract}
Ludwig-Maximilians-Universitat Munchen, Department Biologie I, Systematische Botanik und Mykologie, Menzinger Strase 67, 80638 Munchen, Germany
\end{abstract} \\ Corresponding author: boyce@biologie.uni-muenchen.de
}

\begin{abstract}
Homalomena niahensis P.C. Boyce, is described and illustrated as a new species of Homalomena [Homalomena Clade] locally endemic to Niah Caves, Sarawak, Malaysian Borneo, where it is obligated to Karst limestone. Homalomena niahensis is the sixth species to be described for the Homalomena Selaburensis Complex to which its nearest congener is Homalomena selaburensis. An identification key to species of the Homalomena Selaburensis Complex is provided.
\end{abstract}

Keywords: Araceae, Borneo, Homalomena, Malaysia, Sarawak, Karst limestone

\section{INTRODUCTION}

The Homalomena Selaburensis Complex (Ng et al., 2011) of the Homalomena Clade (Wong et al., 2013a \& b) currently comprises five described species of aromatic-tissued mesophytic herbs distinguished by leaf blades adaxially moderately to highly polished and abaxially always matte with numerous pellucid vein-like glands running parallel to the primary lateral veins, often minutely scabridulous petioles, nodding inflorescences with green unconstricted spathes, and the spathe limb interior surface conspicuously glandular, anthers lacking an expanded connective, by pistils each associated with a clavate to cylindrical staminode, and by spathes that do not alter colour as the developing fruits mature.

At the present time one species of the Selaburensis Complex, Homalomena curvata Engl., is recognized for Peninsular Malaysia, although the taxonomy of the Peninsula species remains imperfectly understood, and five species, including that described here, from Borneo. The Bornean species are all locally endemic and respectively geologically obligated: Homalomena caput-gorgonis S.Y. Wong \& P.C. Boyce (Wong \& Boyce, 2014) is restricted to acidic granites of Gunung Pueh on the northern limit of the Pueh-Berumput range of NW Sarawak; H. galbana Baharuddin \& P.C. Boyce (Baharuddin \& Boyce, 2010) occurs on sandstones in the Maliau Basin (Sabah); H. passa S.Y. Wong \& P.C. Boyce (Wong et al., 2013a \& b) on shales at Mulu National Park (N.P.); and H. selaburensis P.C. Boyce \& S.Y. Wong (Boyce \& Wong, 2014) is found only on the forested Triassic-Jurassic Karst in southern Serian Division. Additional to these described species, fieldwork and subsequent cultivation of plants, necessitated by plants in the wild most frequently being encountered sterile or postanthesis, is revealing occurrences of morphologically rather similar plants for other localities which on flowering are revealed to be undescribed. One such example, a plant not uncommon at Niah Caves N.P., is the subject of this paper. Despite being of striking appearance by virtue of the highly polished leaf blades, the Niah species, although assignable to the Selaburensis Complex based on vegetative characteristics has only recently flowered and shown itself to be undescribed.

Dimensions in the descriptions are derived from fertile (i.e. mature) plants. Seedlings have overall smaller measurements.

Geological occurrences are verified using Tate (2001). 
Key to Species of the Homalomena Selaburensis Complex

1. Petioles and peduncles glossy, smooth ... . . 2

- Petioles and peduncles matte, often scabridulous .................. 3

2. Leaf blades hastate, posterior lobes directed outwards; leaf blade smooth, or only very weakly quilted; peduncle slender, up to $20 \mathrm{~cm}$ $\times 1.5 \mathrm{~mm}$; pistillate flower zone equalling the staminate zone; spathe interior white at anthesis. Mulu (NE Sarawak), shales .... . . ................. Homalomena passa

- Leaf blades sagittate, posterior lobes directed inwards; leaf blade quilted between primary lateral veins; peduncle rather stout, up to 12.5 $\mathrm{cm} \times 3 \mathrm{~mm}$; pistillate flower zone about half as long as the staminate zone; spathe interior yellow at anthesis. Maliau Basin (Sabah), sandstones ......... Homalomena galbana

3. Inflorescences paired. Peninsular Malaysia, granites ............ Homalomena curvata

- Inflorescences up to 30 in a synflorescence. Borneo, various geologies ........... 4

4. Inflorescences up to 30 together in a gorgonoid synflorescence; leaf blades adaxially semi-glossy, abaxially matte olivegreen with deeper green pellucid vein-like glands; plants up to $1.2 \mathrm{~m}$ tall. Gunung Pueh (NW Sarawak), granites ............... ........... Homalomena caput-gorgonis

- Inflorescences up to 7 in a simple synflorescence; leaf blades adaxially highly polished, abaxially matte pale green with darker pellucid vein-like glands; plants up to $55 \mathrm{~cm}$ tall ...................5 5

5. Spadix stipitate, c. 2/3 length of spathe; staminate flower zone ellipsoid; pistils c.1 $\mathrm{mm}$ tall, pale green; spathe limb interior pale green with paler glands. Serian (SW Sarawak), Triassic-Jurassic Karst limestone .............. Homalomena selaburensis

- Spadix sessile (or nearly so), c. 1/2 length of spathe; staminate flower zone stoutly clavate; pistils c. $2 \mathrm{~mm}$ tall, medium green; spathe limb interior olive green with paler glands. Niah Caves (NE Sarawak), Miocene Karst limestone ......... Homalomena niahensis

\section{Species Description}

Homalomena niahensis P.C. Boyce, sp. nov. (Figure $1 \& 2 \mathrm{~A}$ ).

\section{Diagnosis:}

Homalomena niahensis most nearly approaches Homalomena selaburensis by leaf blades adaxially, highly polished and abaxially matte pale green with darker pellucid vein-like glands, and by producing up to seven inflorescences in a simple synflorescence but is readily differentiated by the sessile (not stipitate) spadix, that is c. $1 / 2$ (vs $2 / 3$ ) the length of the spathe, by the larger (c. $2 \mathrm{~mm}$ vs $1 \mathrm{~mm}$ ) medium green (not very pale green) pistils, the stoutly clavate (vs ellipsoid) staminate flower zone, and by the olive green (not pale green) spathe limb interior.

\section{Type:}

MALAYSIAN BORNEO. Sarawak, Miri Division, Niah Suai, Niah N.P., Gunung Subis, along trail to Great Cave, $3^{\circ} 49^{\prime} 09.9^{\prime \prime} \mathrm{N}$ $113^{\circ} 466^{\prime} 52.3^{\prime \prime E}, 13$ Oct 2005, P.C. Boyce, Jeland ak Kisai \& Jepom ak Tisai AR-1423 (Holotype: $\mathrm{SAR}$; isotype SAR - alcohol preserved).

\section{Ecology \& distribution:}

Lowland moist forest on Miocene Karst limestone, between 30-50 m asl.

\section{Description:}

Medium-sized clumping evergreen, aromatic (reminiscent of Juniperus resin) mesophytic herbs to $45 \mathrm{~cm}$ tall. Stem epigeal, erect, leafy, later older parts leafless and decumbent with active tip ascending. Leaves ca. 8 per module, ca. 8-15 together; modules subtended by a conspicuously 2-keeled prophyll up to $7 \mathrm{~cm}$ long; petioles up to $20 \mathrm{~cm}$ long, sheathing for $1 / 4-1 / 3$ their length, ascending to spreading, flexing slightly upwards at $2-3 \mathrm{~cm}$ long pulvinus occurring ca. 2/3 along petiole length, with $1 / 3$ of petiole lying distal to pulvinus, petiole above petiolar sheath weakly D-shaped in cross section, with distal-most ca. $6 \mathrm{~cm}$ shallowly dorsally grooved, dorsal edges bluntly rounded, petiole medium dull medium green, minutely scabridulous; petiolar sheath conspicuous, persistent, margins incurved except, sheath 


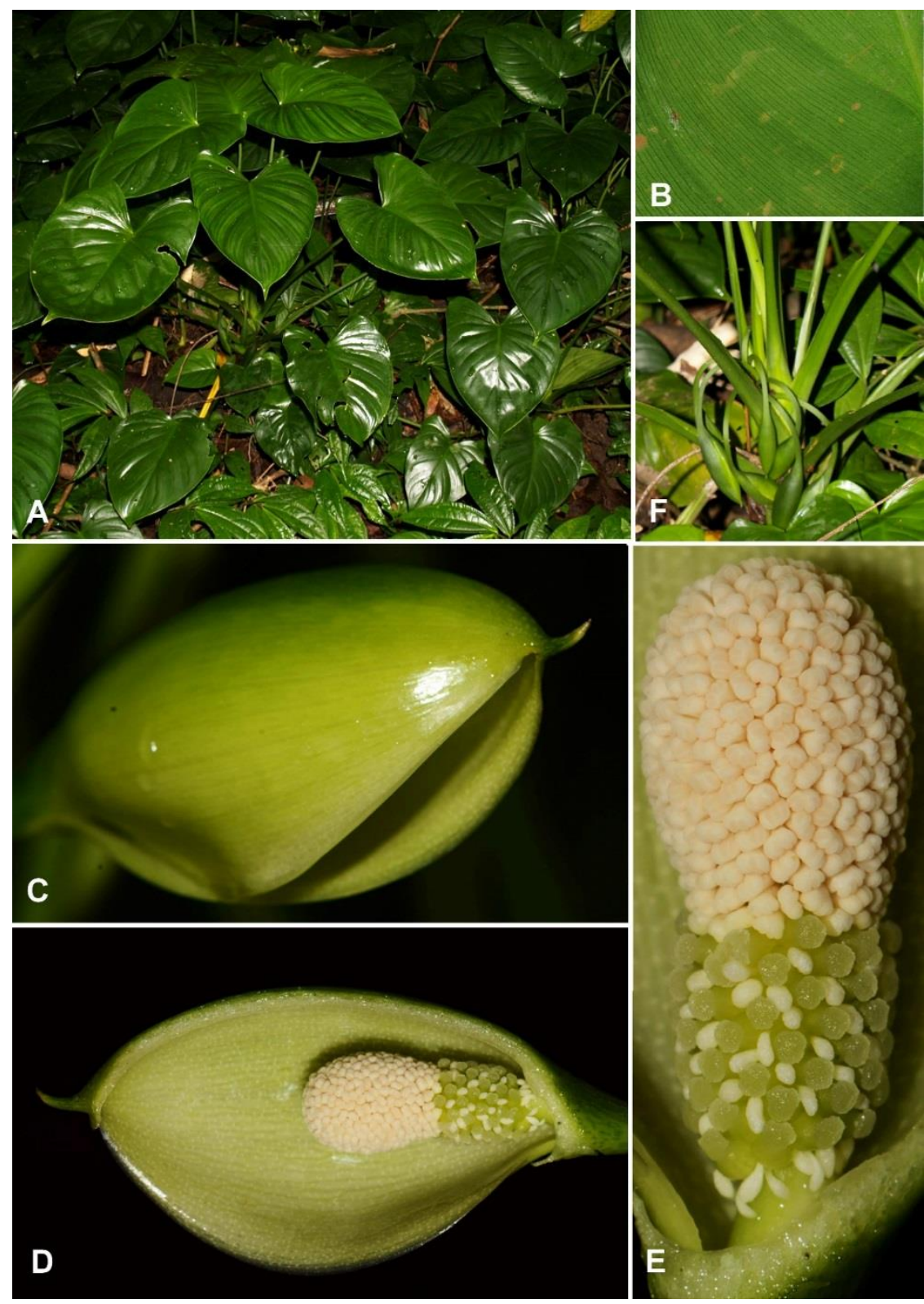

Figure 1. Homalomena niahensis P.C. Boyce, sp. nov. A. Plants in habitat. B. Detail of leaf blade abaxial surface showing pellucid vein-like glands. C Inflorescence at pistillate anthesis. D. Inflorescence at pistillate anthesis, nearside spathe artificially removed. E. Spadix at early pistillate anthesis. F. Fruiting plant in habitat. Note the declinate infructescences, each enclosed in a persistent green spathe.

coloured as for petiole; leaf blade up to $20 \times 13$ $\mathrm{cm}$; cordiform, posterior lobes parallel to somewhat incurved, rounded, sinus obtuse, apex acute, tubular- mucronate for c. $2 \mathrm{~mm}$, highly polished dark green adaxially, abaxially matte pale green with conspicuous darker pellucid striate interprimary venation especially near blade margins; midrib moderately conspicuous, impressed adaxially, rounded-raised abaxially; primary lateral veins up to 9 per side, the lower 2 or 3 arising simultaneously and associated with posterior lobes, impressed adaxially, slightly raised abaxially; interprimary veins of two types, one type alternating with primaries and only slightly less conspicuous, second type comprising conspicuous pellucid darker veins, these very numerous and sometimes branching just after exiting midrib; secondary and tertiary venation nearly invisible. Inflorescences up to 7 together, produced sequentially in a simple synflorescence; peduncle somewhat stout, up to $15 \mathrm{~cm} \times 5 \mathrm{~mm}$, spreading with the inflorescence nodding at anthesis, inflorescence with spathe opening ventrally relative to peduncle, medium green heavily speckled deeper green; spathe spreading at pistillate anthesis, 
broadly ovate-ellipsoid, not constricted, ca. $6 \times 3$ $\times 1.5 \mathrm{~cm}$ deep at anthesis, tipped with a rostrate mucro $5 \mathrm{~mm}$ long, margins reflexing during anthesis, spathe exterior bright medium green, slightly glossy, interior olive green with numerous paler glands. Spadix c. 1/2 length of spathe, $3 \mathrm{~cm}$ long, sessile or nearly so; pistillate flower zone c. $1 / 2$ length of spadix, ca. $1.5 \times 0.8$ $\mathrm{cm}$; pistils rather crowded, lageniform, ca. $2 \times$ $0.6 \mathrm{~mm}$, medium green; style short, slightly narrower than ovary; stigma almost equalling ovary in width, capitate, medium green, papillate at pistillate anthesis; interpistillar staminodes oblong-clavate on a short, very slender stipe, almost equalling height of associated pistil, ivory-white, lowermost tending to be to slightly more slender, reflexing markedly; staminate flower zone contiguous with pistillate flower zone, ca. $1.5 \times 1 \mathrm{~cm}$ at widest point, stoutly clavate, ivory; staminate flowers 3-4-staminate, stamens each with two anthers; stamens elongate-globose, connective embedded and almost invisible; thecae opening by a conspicuous lateral slit. Infructescence pendent, spathe fully persistent deep green, ellipsoid, ca. $5.5 \times 2 \mathrm{~cm}$; fruit and seeds not observed.

\section{Etymology:}

The trivial epithet is from the Type locality plus the suffix -ensis, indicating 'from'.

\section{Other material seen:}

MALAYSIAN BORNEO. Sarawak: Miri Division. Gunung Subis, along trail to Great Cave, $3^{\circ} 49.378^{\prime} \mathrm{N} 113^{\circ} 46.535^{\prime} \mathrm{E}, 30$ Mar 2014, Hoe Yin Chen AR-4678 (SAR).

\section{Notes:}

There is compelling evidence for vicariance events leading to local endemism on the spatially isolated Karst limestone formations of Borneo (e.g. Boyce et al., 2010; Wong, 2010; Ting et al., 2012), and specifically for Niah N.P. and Mulu N.P. (Wong \& Boyce, 2011). It is to be fully expected that exploration of further Karst systems will continue to reveal taxonomic novelties.
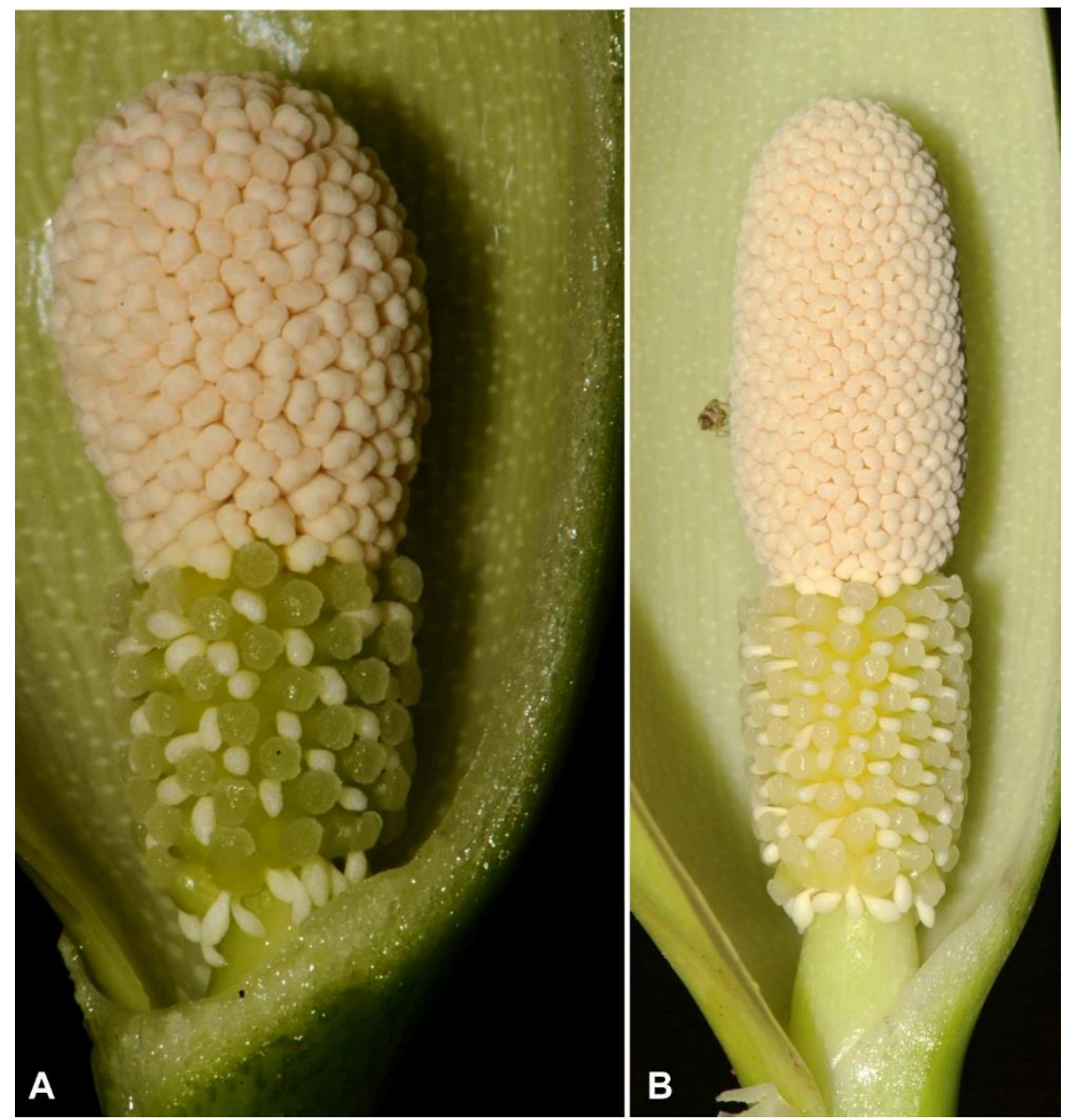

Figure 2. Spadix of A. Homalomena niahensis P.C. Boyce, sp. nov. and B. Homalomena selaburensis P.C. Boyce \& S.Y. Wong compared. 


\section{ACKNOWLEDGEMENTS}

Fieldwork associated with this research was most recently under Sarawak Forestry Department Permission to Conduct Research on Biological Resources Permit No. NPW.907.4.4(JLD.14)-159 and Park Permit No. WL82/2017. The collaboration and support of the Sarawak Forestry Department, the Forest Research Centre (Kuching), and the Sarawak Biodiversity Centre are gratefully acknowledged.

\section{REFERENCES}

Baharuddin, S. \& Boyce, P.C. (2010). Studies on Homalomeneae (Araceae) of Borneo V: A new species and new supergroup record of Homalomena from Sabah, Malaysian Borneo. Tropical Life Sciences Research, 21(2): 89-94.

Boyce, P.C. \& Wong, S.Y. (2014). Studies on Homalomeneae (Araceae) of Borneo XV - A novel limestone-obligated Homalomena from SW Sarawak, Malaysian Borneo. Aroideana, 37: 3843.

Boyce, P.C., Ipor, I.B. \& Hetterscheid, W.L.A. (2010). A review of the white-flowered Amorphophallus (Araceae: Thomsonieae) species in Sarawak. Gardens' Bulletin Singapore, 61(2): 249-268.

Ng, K.K., Ahmad Sofiman, O., Boyce, P.C. \& Wong S.Y. (2011). Studies on Homalomeneae (Araceae) of Borneo VIII: Delimitation of additional informal suprageneric taxa for Sundaic Homalomena. Webbia, 66: 21-28.
Tate, R.B. (2001). The geology of Borneo island CDROM. - Kuala Lumpur: Persatuan Geologi Malaysia / Geological Society of Malaysia.

Ting, A.P.J., Wong, S.Y., Jamliah, J. \& Boyce, P.C. (2012). Phylogenetic study of Schismatoglottis Nervosa Complex (Araceae: Schismatoglottideae). Gardens' Bulletin Singapore, 64(1): 211-219.

Wong, S.Y. (2010). Studies on Schismatoglottideae (Araceae) of Borneo XIII: A revision of the Schismatoglottis nervosa complex. Gardens' Bulletin Singapore, 62(1): 177-209.

Wong, S.Y. \& Boyce, P.C. (2011). Studies on Schismatoglottideae (Araceae) of Borneo XVI: A new species and a further new informal taxon (Multinervia Complex) of Schismatoglottis from Sarawak. Acta Phytotaxonomica et Geobotanics, 60(3): 131-137.

Wong, S.Y. \& Boyce, P.C. (2014). Studies on Homalomeneae (Araceae) of Borneo XVII: Two new species of granite-restricted Homalomena from NW Sarawak. Webbia, 69(1): 69-74.

Wong, S.Y., Tan, P.J., Ng, K.K., Ahmad Sofiman, O., Lee, H.B., Fasihuddin, B.A. \& Boyce, P.C. (2013a). Phylogeny of Asian Homalomena (Araceae) based on the ITS Region Combined with Morphological and Chemical Data. Systematic Botany, 38(3): 589-599.

Wong, S.Y., Hoe, Y.C., Tung, L.S. \& Boyce, P.C. (2013b). Studies on Homalomeneae (Araceae) of Borneo XIII - New Species of Homalomena. Aroideana, 36: 8-29. 